\title{
Arabic Greeting Variations in Surakarta (Sociolinguistic Studies)
}

\author{
Hesti Indah Mifta Nur'aini *), \\ Universitas Sebelas Maret \\ St. Y. Slamet, \\ Universitas Sebelas Maret \\ Budhi Setiawan, \\ Universitas Sebelas Maret \\ *) Correspondences author J1. Ir. Sutami 36A Surakarta, Jawa Tengah, Indonesia \\ e-mail: himnindah@gmail.com
}

\begin{abstract}
This study aims to describe the variation of the greeting words used by Arabians in Surakarta. This study used descriptive qualitative method. The data in this research is the speech language used by the Arab ethnic community in Kecamatan Pasar Kliwon, Surakarta by searching for linguistic features on the variation of the word greeting. Sources of data were obtained from informants who were Arabs in Surakarta. Technique of data analysis using technique of padan. Based on analysis results can be concluded that the variation of Arabic greeting of Arabian community in Surakarta has its own peculiarities. Such distinctiveness is indicated through the greetings associated with pronouns, kinship, social status, and professions used by Arabs more still influenced by the Arabic element. Nevertheless, some of the greetings have shifted in Indonesian and Javanese.
\end{abstract}

Key Words: language variation, greeting, arabic, sociolinguistic.

Article History: Received: 11/06/2018; Revised: 09/08/2018; Accepted: 10/08/2018; Published: 22/08/2018

How to Cite (MLA 7 ${ }^{\text {th }}$ : Nur'aini, Hesti Indah Mifta, St. Y. Slamet, dan Budhi Setiawan. “Arabic Greeting Variations in Surakarta (Sociolinguistic Studies)." Hortatori Jurnal Pendidikan Bahasa dan Sastra Indonesia 2. 1 (2018): 09-14. Print/Online. Copyrights Holder: Nur'aini, Hesti Indah Mifta, St. Y. Slamet, dan Budhi Setiawan. First Publication: Hortatori Jurnal Pendidikan Bahasa dan Sastra Indonesia (2018).

\section{Introductions}

Surakarta is a cultural city thick with Javanese culture. The people who live in Surakarta are mostly Javanese. Nevertheless, Surakarta is also inhabited by other diverse ethnic groups, one of them is Arabs. Arabs in Surakarta tend to live in groups in one region. The area occupied by Arabs in Surakarta is Pasar Kliwon district. In the daily life of Arab ethnic socialize with fellow ethnic as well as interethnic.

The existences of interethnic interactions that live in Surakarta allow variations of language. Interethnic contact and intermingling within society leads to a change in the pattern of language (Tagliamonte, 2012: 40). Cause, goals, speech partners, and situations affect the choice of language used by someone. Basically variations of one's speech can be seen based on time and place. Thus, it can be said that time and geographical position affects the pattern of language variation in society (Irwansyah, Mulyani, and Rokhayati, 2017: 127)

The majority of people in Surakarta use the Javanese language as the main language in communication. Meanwhile, Arabian ethnics are one of the minorities in Surakarta. As minorities, Arabians have their own distinctive language. Speech variation is shown through certain patterns because basically language variation is attached to each individual, group, or society (Tagliamonte, 2012: 21). Cause, minority groups tend to adopt several languages of the majority group reflected in linguistic behavior (Kerswill, 1994: 22). 
The phenomenon of language shift occurs when speakers begin to shift using the dominant language while speaking. In general, this occurs in three generations of immigrants who are a minority will shift using the dominant language. In fact they use both languages as well as part of language preservation (Wardaugh \& Fuller, 2015: 83). The phenomenon of language shift occurred in the Arabs community in Surakarta. This is evidenced from the pattern of daily communication of Arabian ethnic communities in Surakarta who tend to use mixed language. Mixed language used, ex Indonesian, Javanese, and Arabic. While the Arabic language has now started rarely used or only used at certain times and situations.

The Arabians community as a minority group has language variation influenced by the Arabic element. Nonetheless, Javanese and Indonesian as the majority languages also influence the language variations used by Arabian communities. One of the language variations of Arabian community in Surakarta is indicated by a greeting. Greeting is a word that is used to greet others or to mention the speech partner in communication (Haeruddin, 2017: 41; Agus, 2014: 3). In addition, greeting also defined as a word that refers to the word used to refer to a person in a speech event (Kridalaksana, 1982: 14).

The greeting used by the Arabian community in Surakarta needs to be researched because greeting is one important element in communication especially with fellow ethnic. Greeting is an important element in communication so the speaker knows to whom it's addressed. Each language has a varied greeting word system, not least the greeting words used by the Arab ethnic community in Surakarta. The variation of the greeting is influenced by social level and speech component (Rusbiyantoro, 2011: 60). In addition, the word greeting is a form of ethics in social communication. The word hail has an important role in determining one's social status (Saleh 2017: 21). Greeting word is a greeting related to kinship, pronouns, status, and profession.

Previous research on variations of greeting has been done by Wenni Rusbiyantoro (2011) who studied the greetings in Malay Kutai language, while similar research has been done by Haeruddin (2017) who examines the greeting system on the Sasak tribe. Another research result about the word greeting is done by Rahmat Muhidin (2017) who examines the Palestinian ethnic Malay kinship Palembang. While research conducted by R. Saleh (2017) only examines the form of a greeting from the line of kinship in the language of Banjar in Tembilahan, Riau. Imam Suyitno (2017) describe the variations of pronouns people used by people using in banyuwangi. Of the many studies on language variation, so far the research on variations of greeting especially on the Arabian community in Surakarta has never been studied. Therefore, the study of variations of greetings on Arabian ethnic society needs to be studied more deeply. Although the language used by the Arabian community has shifted and changed as a result of the majority language but some Arabic vocabulary is still used in everyday communication, including in the greeting.

\section{Method}

The method in this research is qualitative descriptive. This qualitative research is done by natural setting (Creswell, 2014: 185). The data in this study is the speech language used by the Arab ethnic community in Surakarta by focusing on communication containing the greeting in some situations. Sources of data in this study is the Arab ethnic community in Surakarta. Data collection technique is done through observation, heed technique, and advanced technique. In the advanced technique recording is required. Records in this study were conducted unstructured and semi-structured (Creswel, 2014: 190). The techniques used to analyze the data in this study. Padan technique is the method used to determine the identity of the lingual unit (Sudaryanto, 2015: 15).

\section{Result and Discussions}

Based on the results of research, the greeting data used by Arabs in Surakarta are grouped based on four classes; pronouns, kinship, social status, and professional related greetings.

\section{Forms of Pronouns}

The pronoun is a word used to refer to another noun. The persona pronoun is divided into three, the self-referring pronoun (first person pronoun), refers to the person to whom the pronoun (second person pronouns), and refers to the person in question (third person pronoun) (Alwi, et all, 2008: 249). 


\begin{tabular}{|c|c|c|c|}
\hline No & $\begin{array}{l}\text { Pronouns } \\
\text { Greeting }\end{array}$ & Greetings & Speeches \\
\hline 1. & $\begin{array}{ll}\text { First } & \text { person } \\
\text { pronoun }\end{array}$ & Aku, Saya, Ana & $\begin{array}{l}\text { Aku pinjam bukunya habis UN, ya. } \\
\text { Ana ndak punya fulus. } \\
\text { Nanti, saya yang mengumpulkan. }\end{array}$ \\
\hline 2. & $\begin{array}{l}\text { The second } \\
\text { person's pronoun }\end{array}$ & $\begin{array}{l}\text { Kamu, Kau, Ente, Kamu } \\
\text { Orang, Antum, Anda }\end{array}$ & $\begin{array}{l}\text { Hla kamu kenapa kemarin ndak } \\
\text { masuk? } \\
\text { Kau sama sapa? } \\
\text { Kamu orang lihat dia di mana? } \\
\text { Gimana ente khair, ya? } \\
\text { Kalauantum semua mau berusaha, ya } \\
\text { pasti bisa. } \\
\text { Anda harus bisa memahami } \\
\text { peraturan yang telah ditetapkan. }\end{array}$ \\
\hline 3. & $\begin{array}{l}\text { The third person's } \\
\text { pronoun }\end{array}$ & Dia, Dia Orang, Beliau & $\begin{array}{l}\text { Dia belum tau kalo hari ini pake } \\
\text { abaya. } \\
\text { Kayaknya dia orang hawiyan. } \\
\text { Beliau itu sibuk tapi ya bisa } \\
\text { memenejemen waktu. }\end{array}$ \\
\hline
\end{tabular}

The greeting form based on pronouns used by the Arabian community in Surakarta mostly has similarities to the pronoun in Indonesian. The variation of the first person pronoun appears in Arabian society are three variations, namely $a k u$, saya dan ana. However, in the first person pronoun, a pronoun found is still influenced by the Arabic, i.e. Ana. Ana in Arabic means me. The pronoun aku and ana are used in an informal situation. In the speech shows the familiarity of the situation used when communicating with fellow Arabs. Meanwhile, pronouns saya is used in formal situations.

The second person's pronoun appears in six variations, ie kamu, kau, ente, kamu orang, antum, anda. Kamu, kau, ente, kamu orang, dan antum, are used in informal situations in close relationships such as through family or with friends. While in formal situations such as in education or work domains they tend to use Anda. Pronoun kamu, kau dan anda are Indonesian pronoun. As for the second person pronoun, ente is also the influence of the Arabic, which is anta which means you, while antum is used to call the second person in the plural. In addition, also uniqueness in the second person pronoun and the third person pronoun. The peculiarity of the second person's pronoun appears, i.e. kamu orang. Кати orang have the same function as your pronoun. As for the third person pronoun, the uniqueness, i.e. dia orang. In Informal conversation kau is more often used than kamu pronouns by the Arabs when communicating with fellow ethnicity. Meanwhile, Anda and beliau only used in formal situations.

\section{Form of Greetings Kinship Group}

Kinship relationships in the community can be seen in lineage or marriage line. The following is the variation of the kinship greeting used by the Arabic community in Surakarta.

\begin{tabular}{|r|l|l|l|}
\hline No & \multicolumn{1}{|c|}{$\begin{array}{c}\text { Kinship } \\
\text { Greeting }\end{array}$} & \multicolumn{1}{c|}{ Greetings } & \multicolumn{1}{c|}{ Speeches } \\
\hline 1. & Male parents & Abi, Abah & $\begin{array}{l}\text { Abi nanti bawaken makan siang, ya. } \\
\text { Abah jemput aku jam 3, ya. }\end{array}$ \\
\hline 2. & Female parents & Mamah, ummi, umma & $\begin{array}{l}\text { Seringnya ngobrol pake bahasa Arab } \\
\text { itu sama mamah, Bu. } \\
\text { Ummi kemarin sakit, jadi ngga bisa ke } \\
\text { sekolah. }\end{array}$ \\
\hline
\end{tabular}




\begin{tabular}{|c|c|c|c|}
\hline & & & Umma, aku mau makan. \\
\hline 3. & $\begin{array}{l}\text { Elder siblings } \\
\text { male/female }\end{array}$ & Kakak & $\begin{array}{l}\text { Kak Ana, aku grogi mau sambutan. } \\
\text { Nis, tolong ambilken tugasku yang } \\
\text { ketinggalan di meja. }\end{array}$ \\
\hline 4. & $\begin{array}{l}\text { Younger } \\
\text { siblings } \\
\text { male/female }\end{array}$ & Adik & $\begin{array}{l}\text { Tiap hari yang jaga toko adikku yang } \\
\text { rejjal. }\end{array}$ \\
\hline 5. & $\begin{array}{l}\text { Old man's } \\
\text { brother (from } \\
\text { mother's line) }\end{array}$ & $A m i$ & $\begin{array}{l}\text { Amiku baru kemarin pulang dari luar } \\
\text { kota. }\end{array}$ \\
\hline 6. & $\begin{array}{l}\text { Older sister's } \\
\text { parents (from } \\
\text { mother's line) }\end{array}$ & Ameh & $\begin{array}{l}\text { Besok yang ambil rapot bukan mamah, } \\
\text { Bu tapi ameh } k u \text {. }\end{array}$ \\
\hline 7. & $\begin{array}{l}\text { Old man's } \\
\text { brother (from } \\
\text { father's line) }\end{array}$ & Khal & Khal Ali besok ikut Semarang, ndak? \\
\hline 8. & $\begin{array}{l}\text { Older } r \text { sister's } \\
\text { parents (from } \\
\text { father's line) }\end{array}$ & Khalati & Khalati, nanti Vina main ke rumah, ya. \\
\hline 9. & $\begin{array}{l}\text { Children's } \\
\text { parents brother }\end{array}$ & Misan, Misanan, Mindhoan & Aku sama Virda itu misanan. \\
\hline 10. & $\begin{array}{l}\text { Parents of } \\
\text { father/mother } \\
\text { man }\end{array}$ & Jiddi, Abib, Eyang & $\begin{array}{l}\text { Yang jualan madu itu abibku. } \\
\text { Bojonya Jid Ali itu Kak Elok. } \\
\text { Eyang kabarnya baik, kan? }\end{array}$ \\
\hline 11. & $\begin{array}{l}\text { Parents of } \\
\text { fathers/mothers }\end{array}$ & Jiddah & Jiddahku sakit di rumah sakit. \\
\hline 12. & $\begin{array}{l}\text { Husband and } \\
\text { wife }\end{array}$ & Zauj, Zaujah, Bojo & $\begin{array}{l}\text { Zaujku kerja di Hadramaut. } \\
\text { Bojonya Jid Ali itu Kak Elok. }\end{array}$ \\
\hline
\end{tabular}

To call their father found two variations of the word greeting, namely $a b i$ and $a b a h$. Abi and $a b a h$ are used by a child to call their father in everyday conversation. These two greetings are part of the Arabic vocabulary.

Then to mention their mother found three variations of greetings, namely mamah, ummi, and umma. The greeting ummi and umma is part of the Arabic language while the greeting mamah is part of the Indonesian greeting.

Furthermore, to mention the siblings of both brother and sister of the Arabian community they directly call his name. Similarly, greetings to younger brothers and sister, they greet directly his name.

Misan, Misanan, Mindhoan is the reference pronoun used to refer to cousin. While in greeting, they do not have a special greeting but directly call it by name. The same is true of the words Zauj, Zaujah, Bojo which is a reference pronoun for wife or husband. As for the word greeting they use the greeting like $a b i$ and $a b a h$ to call the husband and Mamah, ummi, umma to call the wife.

Based on kinship, the greetings used by Arabs in Surakarta are still largely influenced by Arabic. The greeting that is still influenced by Arabic, are abi, abah, ummi, umma, ami, ameh, khalati, khalati, misan, misanan, mindhoan, jiddi, abib, jiddah, zauj, and zaujah. However, there is also a kinship term that uses Indonesian and Javanese. Mentioning of kakak, adik, mamah, and eyang is a greeting word in Indonesian. While the kinship term that influenced the language of Java is bojo which means husband or wife.

\section{Form of Group Status Greetings}

Social status is one of the determinants in the election of a greeting. Respect for the elderly and cherish the younger are part of the ethics included in the election of a greeting. 
Table 3 Group Status Greeting

\begin{tabular}{|c|c|c|c|}
\hline No & Status Greeting & Greetings & Speeches \\
\hline 1. & Unmarried men & Kak +name & Kak Mus itu bendaharanya yayasan. \\
\hline 2. & $\begin{array}{l}\text { Unmarried } \\
\text { women }\end{array}$ & Kak + name & $\begin{array}{l}\text { Kak Hira yang punya apotek di } \\
\text { sebelah mesjid As-Segaf. }\end{array}$ \\
\hline 3. & Married man & Kak + name & $\begin{array}{l}\text { Kalau Minggu Kak Muh yang nunggu } \\
\text { toko di Beteng. }\end{array}$ \\
\hline 4. & Married woman & Kak + name & $\begin{array}{l}\text { Saya di sini panggilannya Kak Ana, } \\
\text { bukan Bu Ana. }\end{array}$ \\
\hline 5. & Very old man & $A b i b$ & $\begin{array}{l}\text { Abib yang meninggal itu tinggalnya di } \\
\text { deket Sampangan. }\end{array}$ \\
\hline 6. & Very old woman & Ummi, Jiddah & $\begin{array}{l}\text { Ummi masih berani naik motor } \\
\text { sendiri? } \\
\text { Jiddah mau minum sahi? }\end{array}$ \\
\hline 7. & $\begin{array}{l}\text { Female/male } \\
\text { household } \\
\text { assistant }\end{array}$ & Sambatan, mas, mbak & $\begin{array}{l}\text { Mbak Tentrem itu sambatan di } \\
\text { rumahku. }\end{array}$ \\
\hline
\end{tabular}

Greetings from the status of men or women whether married or unmarried using the same greeting, is kak. This is shown in data (1), (2), (3), and (4) which have no differences. The context of speech on data (1) and (2) are unmarried males and females whereas data (3) and (4) are married men and women. Kak is a short form of greeting kakak. In the greeting Kak followed by the name. In general, in Surakarta the greeting for unmarried men and women is mas or mbak, while the word greeting for married men and women is usually called by pak or $b u$.

The greeting for very old men and women is the same as the kinship greeting. They chose to use greetings ummi, jiddah, and abib. Meanwhile, for a household assistant name they call it a sambatan. Sambatan comes from the Javanese word meaning helper. In this case they call as mbak for female helper and mas for male helper.

\section{Form of Group Profession}

Based on the profession or position in communicating required appropriate greeting. The word greeting is used instead of pronouns persona.

Table 4 Profession Greeting

\begin{tabular}{|r|l|l|l|}
\hline No & \multicolumn{1}{|c|}{$\begin{array}{c}\text { Profession } \\
\text { Greeting }\end{array}$} & \multicolumn{1}{|c|}{ Greeting } & \multicolumn{1}{c|}{ Speeches } \\
\hline 1. & $\begin{array}{l}\text { Muslim religious } \\
\text { teachers are men }\end{array}$ & Ustaz & Ustaz nanti sore tahfid? \\
\hline 2. & $\begin{array}{l}\text { Islamic female } \\
\text { teachers of Islam }\end{array}$ & Ustazah & $\begin{array}{l}\text { Yang ngajar hadroh nanti ustazah } \\
\text { siapa? }\end{array}$ \\
\hline 3. & $\begin{array}{l}\text { Religious leaders } \\
\text { of Islam }\end{array}$ & Ustaz, Habib & $\begin{array}{l}\text { Tiap dua minggu sekali yang ngisi } \\
\text { kajian ustaz Umar. } \\
\text { Besok kajian yang ngisi Habib Syeh. }\end{array}$ \\
\hline 4. & Teacher & Pak/Bu Guru & $\begin{array}{l}\text { Bu guru, saya ngijinken Latifah } \\
\text { tidak masuk, baru sakit. }\end{array}$ \\
\hline
\end{tabular}




\begin{tabular}{|r|l|l|l|}
\hline 5. & Merchants & Pedagang & $\begin{array}{l}\text { Pekerjaannya abahku pedagang } \\
\text { oleh-oleh khas Arab di kompleks } \\
\text { mesjid Riyadh. }\end{array}$ \\
\hline
\end{tabular}

The greeting used by the Arab ethnic community related to the profession is mostly the same as the profession speeches in Indonesian as shown in the greetings for teachers and merchants. In Javanese or Indonesian, muslim religious leaders are usually called kiai or ustaz. However, Arabs in Surakarta tend to call it Habib.

\section{Conclusions}

Greeting variations of Arabian in Surakarta are still influenced by Arabic. Nevertheless, some greetings are also influenced by Javanese because Arabs in Surakarta live side by side with Javanese ethnic as dominant in Surakarta. Besides that, other greetings have also partially shifted from Arabic to Indonesian. The dominant language factor becomes the biggest influence of the shifting of language is no exception in greetings. Thus, it can be concluded that the variation of the greeting used by Arabian in Surakarta uses Arabic, Javanese, and Indonesian.

\section{Acknowledgement}

Thank you the author convey to the supervisor and Chairman of S-2 Indonesia Language Education of Sebelas Maret University who approved this research. The authors also thank the informants, the Arab ethnic community in Pasar Kliwon, Surakarta for their willingness and cooperation in this research.

\section{References}

Agus, N. Bentuk Sapaan Bahasa Bugis dalam Konteks Pragmatik Gender. Sawerigading. 20(1), 1-13, 2014.

Alwi, H., et all. Tata Bahasa Baku Bahasa Indonesia. Jakarta: Balai Pustaka, 2008.

Creswell, J. W. Research Design: Qualitative \& Quantitative Approaches. California: Sage Publications, Inc, 2014.

Haerudin. Sistem Sapaan Kekerabatan Suku Sasak: Kajian Linguistik Kebudayaan. Lingua: Journal of Language, Literature and Teaching. 14(1), 39-54, 2017.

Irwansyah, N, Sri Mulyani, and Reni Rokhayati. The Use of Batavia Language in South Jakarta (Study of Sociodialectology). Hortatori Jurnal Pendidikan Bahasa dan Sastra Indonesia. 1(2) 126-130, 2017.

Kerswill, P. Dialects Converging: Rural Speech in Urban Norway. Oxford: Oxford University Press on Demand, 1994.

Kridalaksana, H. Dinamika Tutur Sapa dalam Bahasa Indonesia. Jakarta: Bahatara, 1982.

Muhidin, R. Leksikon Kekerabatan Etnik Melayu Palembang. Ranah, 6(1), 84-99. 2017.

Rusbiyanto, W. Penggunaan Kata Sapaan dalam Bahasa Melayu Kutai. Parole, 2(1), 59-76, 2011.

Saleh, R. Bentuk Sapaan Kekerabatan dalam Bahasa Banjar di Tembilahan, Riau. Madah, 8(1), 19-32, 2017.

Sudaryanto. Metode dan Aneka Teknik Analisis Bahasa. Yogyakarta: Sanata Dharma University Press, 2015.

Suyitno, I. The Persons Pronouns of Using Language and Its Use in Banyuwangi Speech Community. Researchers World Journal of Arts, Science \& Commerce, 8(2), 113-121, 2017.

Tagliamonte, S. Variationist Sociolinguistics: Change, Observation, Interpretation. Southern Gate: John Wiley \& Sons, 2011.

Wardhaugh, R. An Introduction to Sociolinguistics. Malden: John Wiley \& Sons, 2010. 